TESL A | VOL. 22 | NO. 2 | OKTOBER 2020 |

\title{
POTENSI ENERGI PANAS BUMI, ANGIN, DAN BIOMASSA MENJADI ENERGI LISTRIK DI INDONESIA
}

\author{
Nurul Amandha Adistia ${ }^{1}$ \\ Program Studi Teknik Elektro President University \\ Email: nurulamandha27@gmail.com \\ Rizky Aditya Nurdiansyah ${ }^{1}$ \\ Program Studi Teknik Elektro President University \\ Email: rizkyadityanurdiansyah@gmail.com \\ Juno Fariko ${ }^{1}$ \\ Program Studi Teknik Elektro President University \\ Email: junofariko35@gmail.com \\ Vincent $^{1}$ \\ Program Studi Teknik Elektro President University \\ Email: vincentsudiono@ outlook.com \\ Joni Welman Simatupang ${ }^{1}$ \\ Program Studi Teknik Elektro President University \\ Email: joniws@ieee.org
}

\begin{abstract}
S: The need of energy increases each year. Likewise, the need for electrical energy increased proportionally with the economic development and Indonesian populations. To meet the needs of national electrical energy, the implementation of new and renewable energy is indispensable, such as geothermal energy, wind and biomass. They have substantial potential in Indonesia. This research aims to explore Indonesia's capacity of new and renewable energy for electrical energy, as well as how much energy that can has already been utilized, and the constraints such as natural and human resources or other factors, to achieve the fulfil the target in 2025 about fulfilment of national electrical energy needs. This research uses Systematic Literature Review (SLR). The data are secondary, which are collected from several journals, research articles, media, and government agency reports, especially the Ministry of energy and mineral resources (ESDM). The result shows that for the installed capacity in the plan for 2019 - 2028, wind energy contributes the highest with 82,76\%. Geothermal contributes $25.31 \%$, and biomass contributes $4.92 \%$. In fact, in this year of 2020, new and renewable energy could not meet the government's target. Several factors that impede the development of new and renewable energy, especially the geothermal, wind, and biomass, are funding, bad-coordinated plan, and also the implementation. Additionally, there is COVID-19 pandemic in 2020, and all funds are diverted for the treatment of the pandemic crisis.
\end{abstract}

Keyword: Biomass; Geothermal; Potency; Systematic Literature Review (SLR); Wind.

ABSTRAK: Kebutuhan akan energi terus meningkat seiring dengan bertambahnya waktu. Begitupun kebutuhan energi listrik yang semakin meningkat seiring perkembangan perekonomian dan penduduk Indonesia. Untuk memenuhi kebutuhan energi listrik nasional, maka peran Energi Baru Terbaharukan (EBT) sangat diperlukan, diantaranya panas bumi, angin, dan biomassa. Ketiga energi tersebut memiliki potensi yang cukup besar di Indonesia. Penelitian ini bertujuan untuk mengetahui potensi EBT di Indonesia menjadi energi listrik, serta seberapa besar energi yang sudah dapat dimanfaatkan, dan juga kendala-kendala baik alam maupun sumber daya manusia ataupun faktor lain, agar dapat mencapai target terdekat yaitu di tahun 2025 sebagai pemenuhan kebutuhan listrik negara dari EBT. Penelitian ini menggunakan metode Systematic Literature Review (SLR). Data yang dikumpulkan bersifat data sekunder, yaitu berupa pengumpulan jurnal dan artikel penelitian yang sudah ada, dari media massa, dan laporan dari badan pemerintah, khususnya kementerian ESDM. Berdasarkan hasil analisis kapasitas terpasang terhadap rencana energi tahun 2019-2028, energi angin memiliki persentase terbesar yaitu $82,76 \%$, panas bumi sebesar $25,31 \%$, dan biomassa sebesar 4,92\%. Pada kenyataannya di tahun 2020 ini, EBT belum bisa mencapai target yang sudah ditetapkan oleh pemerintah. Hal ini dipengaruhi beberapa faktor penghambat kemajuan proyek pembangunan ataupun peningkatan hasil EBT khususnya panas bumi, angin, dan biomassa, seperti pendanaan, perencanaan yang tidak terkoordinasi dengan baik, dan implementasi yang sulit. Selain itu, di tahun 2020 masih terjadi pandemi COVID-19 yang menjadi faktor penghambat karena semua dana dialihkan untuk penanganan krisis pandemi.

Kata Kunci: Angin; Biomassa; Panas bumi; Potensi; Systematic Literature Review (SLR).

\section{PENDAHULUAN}

$\mathrm{K}$ ebutuhan energi listrik terus meningkat seiring dengan perkembangan perekonomian dan penduduk, termasuk juga di Indonesia. Di tahun 2020, terjadi pandemi COVID-19, dan di Indonesia telah diterapkan

\footnotetext{
1 Program Studi Teknik Elektro President University, Cikarang, Jawa Barat
} 
Pembatasan Sosial Berskala Besar (PSBB) yang diatur dalam Peraturan Menteri Kesehatan (Permenkes) nomor 9 tahun 2020, untuk percepatan penanganan pandemi COVID-19 [1]. Salah satu kebijakan yang diterapkan yaitu Work From Home (WFH) dari beberapa sektor industri dan bisnis. Hal ini membuat kebutuhan listrik di rumah mengalami pengingkatan selama tiga bulan terakhir (Maret, April, dan Mei). Hal ini dikarenakan sejumlah aktivitas masyarakat, khususnya pekerja, lebih banyak melakukan kegiatan dari rumah. Berbeda dengan penggunaan listrik di industri dan sektor bisnis, perdagangan, transportasi, pariwisata, dan sektor lainnya, yang justru berkurang. Berdasarkan data yang disampaikan oleh Senior Manager Niaga dan Pelayanan Pelanggan PT. PLN (Persero) Unit Induk Distribusi (UID) Jawab Barat, Rino Gumpar Hutasoit, yaitu pelanggan rumah tangga pada periode WFH naik $13-20 \%$ per bulan, sedangkan konsumsi listrik di industri turun $40 \%$, sektor bisnis turun 20\%, dan untuk sosial dan pemerintah masing-masing turun $10 \%$ [2].

Ada beberapa macam energi yang bisa dimanfaatkan, salah satunya adalah Energi Baru Terbarukan (EBT) yang merupakan energi yang berasal dari alam dan dapat diperbaharui. Apabila energi tersebut digunakan dengan baik, maka energi tersebut tidak akan habis. Pemanfaatan energi terbarukan terbagi menjadi energi yang sudah dikembangkan namun secara terbatas, dan yang sudah dikembangkan namun masih pada tahap penelitian. Untuk memenuhi kebutuhan energi nasional, maka peran EBT sangat diperlukan. Berdasarkan PP nomor 79 tahun 2014 mengenai Kebijakan Energi Nasional, di mana target bauran EBT sebesar 23\% pada tahun 2025, dan $31 \%$ pada tahun 2050 [3]. Beberapa bentuk EBT di Indonesia dengan potensi yang sangat besar adalah panas bumi, angin, dan biomassa. Hal ini dipengaruhi oleh keadaan astronomis dan geografis Indonesia di garis khatulistiwa, sehingga Indonesia beriklim tropis.

Energi panas bumi merupakan energi yang diekstrak dari sistem hidrotermal yang merupakan sistem vulkanisme serta pembentukkan gunung berapi pada perbatasan lempeng aktif. Indonesia sendiri terletak pada pertemuan tiga lempeng aktif sehingga memungkinkan energi ini untuk ditransfer ke permukaan bumi melalui sistem rekahan. Keadaan geografis Indonesia yang strategis ini memberikan potensi yang sangat besar, khususnya untuk menghasilkan energi listrik. Energi ini merupakan EBT yang ramah lingkungan dibandingkan dengan energi fosil. Energi ini tidak dapat dipindahkan atau diekspor sehingga diharapkan memenuhi kebutuhan listrik negara [4]. Berdasarkan UU no. 27 tahun 2003 serta UU no. 20 tahun 2002, telah dibuat peta perjalanan (road map) panas bumi yang dapat digunakan sebagai pedoman, pola pengembangan, dan pemanfaatan energi ini. Pemanfaatan tenaga listrik dapat mencapai $6000 \mathrm{MW}$ dan diharapkan ada pengembangan untuk pemanfaatan secara langsung pada sektor agribisnis, pariwisata, dan sektor lainnya pada tahun 2020 [5]. Dari 252 area yang telah diidentifikasi, diperoleh data dengan total potensi sumber daya dan cadangan panas bumi sebesar 27.357 MW. Namun baru 3\% dengan jumlah 807 MW yang telah dimanfaatkan sebagai energi listrik, dengan 2\% merupakan pemakaian energi listrik nasional. Untuk memenuhi target pengembangan panas bumi sebesar 6000 MW, serta pemakaian EBT non-hidro berskala besar, yaitu lebih dari 5\%, maka diperlukan percepatan investasi di tahun 2020. Selain itu, pemerintah sudah menyiapkan peta saran WKP dengan total 28 lokasi, berdasarkan besarnya potensi energi di wilayah 33 WKP yang telah ada [4].

Selain itu, ada pula energi angin. Angin sendiri merupakan udara yang bergerak dari tempat bertekanan tinggi ke rendah. Hal ini terjadi karena tidak meratanya radiasi matahari di permukaan bumi, sehingga terjadi perbedaan suhu udara. Energi ini dapat diubah menjadi energi listrik dengan menggunakan kincir angin. Besarnya energi listrik yang dihasilkan akan bergantung pada kecepatan angin, di mana kecepatan angin dipengaruhi oleh keras permukaan dan penghalang, seperti gedung dan pohon. Selain itu, ketinggian lokasi juga berpengaruh terhadap kecepatan angin. Potensi energi angin di Indonesia telah diidentifikasi dengan nilai sekitar $978 \mathrm{MW}$ dengan rata-rata kecepatan angin berkisar antara 3,5-7 m/s. Wilayah dengan potensi terbesar adalah di Sulawesi Selatan, di mana energi listrik yang dihasilkan dapat mencapai lebih dari 200 MW. Teknologi turbin angin skala besar dapat bekerja dengan baik pada kecepatan 5-20 m/s. Sedangkan kecepatan di bawah $5 \mathrm{~m} / \mathrm{s}$ lebih sesuai untuk diubah menjadi energi mekanik atau pembangkit listrik tenaga angin dengan skala kecil. Selain itu, penggunaan turbin angin dengan poros vertikal juga lebih cocok untuk daerah dengan kecepatan angin di bawah $5 \mathrm{~m} / \mathrm{s}$ [6]. Untuk implementasi turbin angin dalam kehidupan nyata, sudah pernah dilakukan dalam skala laboratorium untuk pengisian daya seperti ponsel pintar (smartphone) [7].

Biomassa adalah bahan organik yang berasal dari sisa metabolisme tumbuhan atau hewan, maupun limbah yang dihasilkan. Material organik hidup seperti ini biasanya mengandung air dengan kadar berkisar antara $80-90 \%$. Setelah kering, material organik memiliki kandungan senyawa hidrokarbon yang sangat tinggi. Senyawa inilah yang sangat penting untuk menjadi potensi sumber energi. Indonesia sebagai negara agraris, umumnya memiliki limbah hasil pertanian yang kurang termanfaatkan, dan limbah ini bisa digunakan sebagai alternatif energi biomassa [8]. Energi ini memiliki keuntungan dalam pemanfaatannya antara lain: dapat dimanfaatkan secara berulang karena sifatnya yang renewable, tidak mengandung unsur sulfur sehingga tidak akan menyebabkan polusi udara sama seperti pada bahan bakar fosil, serta dapat meningkatkan efisiensi pemanfaatan limbah pertanian [9]. Pertengahan tahun 2015, pengembangan biomassa untuk pembangkit listrik 
tenaga biomassa, biogas, dan sampah menghasilkan kapasitas sebesar 91,1 MW yang terpasang secara on-grid (terinterkoneksi ke jaringan PLN), serta 1.626 MW yang belum on-grid [10].

Kapasitas pembangkit tenaga listrik terpasang sampai tahun 2018 mencapai 64,5 GW. Sebagian besar berasal dari energi fosil, khususnya batubara (50\%,) gas bumi (29\%), EBT (14\%), dan BBM (7\%), sebagaimana ditunjukkan dalam Gambar 1 di bawah ini.

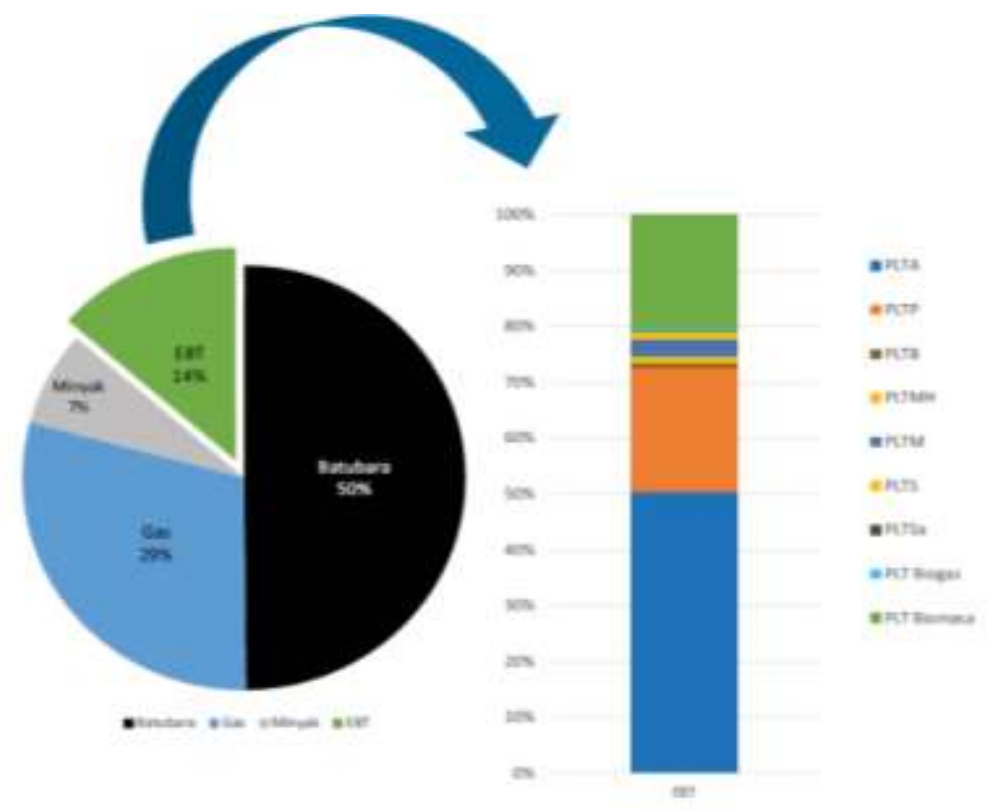

Gambar 1. Kapasitas terpasang pembangkit listrik per jenis energi tahun 2018 [11].

Sejauh ini EBT di Indonesia belum termanfaatkan secara optimal, sehingga target pemasangan EBT khususnya panas bumi, angin, dan biomassa belum tercapai. Berdasarkan kondisi ini, maka timbul rumusan masalah yaitu:

1. Bagaimana perkembangan potensi energi panas bumi?

2. Mengapa EBT belum memenuhi target dalam pemanfaatannya menjadi energi lisrik, dan apa saja faktor yang mempengaruhinya?

Secara umum, penelitian ini dilaksanakan untuk mengetahui potensi EBT di Indonesia menjadi energi listrik serta seberapa besar energi yang sudah dapat dimanfaatkan, serta kendala-kendala yang ada, baik alam maupun sumber daya manusia ataupun faktor lainnya, untuk dapat mencapai target terdekat yaitu pada tahun 2025 sebagai pemenuhan kebutuhan listrik negara dari energi baru dan terbarukan.

Ada beberapa metode yang dapat digunakan untuk menjawab rumusan masalah di atas. Salah satu caranya adalah dengan mengambil data langsung dari lapangan. Namun mempertimbangkan pandemi COVID-19 yang sedang terjadi saat ini, metode tersebut menjadi kurang cocok untuk dilaksanakan. Metode yang lebih cocok adalah dengan menggunakan Systematic Literature Review (SLR) yang berfokus pada pengumpulan data sekunder. Meskipun data yang dipakai bukan merupakan data terbaru, namun rentang data yang diambil masih sangat relevan untuk dianalisa.

\subsection{Energi Panas Bumi}

\section{LANDASAN TEORI}

Energi panas bumi merupakan salah satu EBT yang berasal dari pusat bumi. Radioaktif yang meluruh menimbulkan panas dari dalam, dan ditambah dengan panas matahari yang membuat permukaan bumi menjadi panas. Beberapa cara untuk memanfaatkan energi ini antara lain:

1. Membangun pembangkit listrik,

2. Membuat pipa ke yang menuju langsung ke perut bumi yang menjadi sumber panas,

3. Memompa langsung panas dari dalam perut bumi.

Panas bumi merupakan bentuk dari energi panas yang dihasilkan serta disimpan di dalam bumi. Energi panas sendiri menentukan temperatur suatu benda. Beberapa sumber untuk energi ini adalah hasil dari pembentukan planet dengan total $20 \%$ serta hasil dari peluruhan radioaktif mineral dengan nilai sebesar $80 \%$. Gradien panas bumi yang merupakan perbedaan suhu dari inti bumi dan permukaannya, mengendalikan konduksi kontinu dalam bentuk energi panas, khususnya dari inti ke permukaan bumi. 
Dengan temperatur inti bumi yang dapat mencapai lebih dari $5000^{\circ} \mathrm{C}$, panas dapat mengalir secara konduksi menuju bebatuan di sekitarnya, serta menjadikan bebatuan tersebut meleleh hingga akhirnya membentuk magma. Magma ini kemudian mengalirkan panas tersebut secara konveksi, sambil bergerak naik. Hal ini dikarenakan magma yang wujudnya adalah cairan memiliki masa jenis yang lebih rendah dari bebatuan yang padat. Magma kemudian menaikkan suhu kerak bumi serta air yang mengalir di dalamnya. Suhu yang terjadi dapat mencapai $300^{\circ} \mathrm{C}$. Air yang panas ini kemudian menimbulkan tekanan tinggi sehingga air dapat keluar dari kerak bumi. Panas dari dalam perut bumi ini juga dapat menciptakan uap yang kemudian dapat digunakan untuk menggerakkan turbin untuk berbagai keperluan, salah satunya untuk produksi energi listrik, seperti ditunjukkan pada Gambar 2. Cairan kemudian dikembalikan lagi ke dalam bumi untuk dipompa lagi ke atas dalam bentuk uap. Siklus ini terjadi secara terus menerus. Meskipun pada awalnya membutuhkan biaya yang mahal, namun biaya operasionalnya dapat lebih rendah daripada pembangkit listrik dari bahan bakar fosil [12].

Indonesia termasuk negara berkembang dengan peningkatan permintaan energi listrik mencapai $10 \%$ per tahunnya. Hal ini tentu menjadikan Indonesia sebagai negara yang perlu meningkatkan pasokan energi listrik, dengan kapasitas sekitar $6 \mathrm{GW}$ per tahunnya. Oleh sebab itu, harapan Indonesia pada pembangkit listrik panas bumi cukup besar [12].

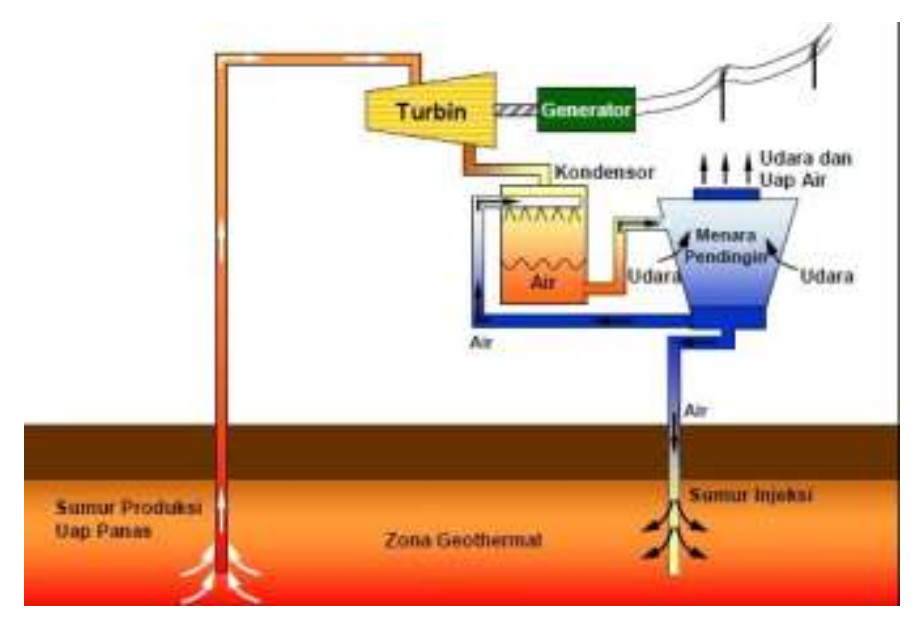

Gambar 2. Skema prinsip kerja energi panas bumi [13]

\subsection{Energi Angin}

Perbedaan suhu pada dua tempat berbeda dapat menghasilkan perbedaan pada tekanan udaranya. Hal ini kemudian menghasilkan angin. Angin sendiri merupakan gerakan materi seperti udara dan dapat menggerakkan turbin dengan kecepatan tertentu. Turbin angin dimanfaatkan untuk menghasilkan energi, seperti energi kinetik dan energi listrik. Energi ini proposional dengan kecepatan angin. Artinya, meningkatnya kecepatan angin membuat energi yang dihasilkan juga meningkat, bahkan dapat mencapai limit tertinggi energi yang mampu dihasilkan. Tempat dengan kekuatan angin yang lebih tinggi dan juga konstan, seperti lepas pantai dan dataran tinggi, biasanya diutamakan untuk dibangun pembangkit energi angin [12].

Prinsip kerja Pembangkit Listrik Tenaga Bayu (PLTB) adalah dengan menggunakan kincir angin untuk mengkonversi energi angin menjadi energi kinetik, lalu kemudian menjadi energi listrik. Energi kinetik dari angin dapat masuk ke dalam turbin sehingga kincir angin mampu berputar. Hal ini menggerakan generator untuk membangkitkan energi listrik. Daya turbin angin bergantung pada beberapa faktor seperti volum, densitas, serta kecepatan angin. Cara kerja kincir angin pada Gambar 3 dapat diuraikan sebagai berikut. Angin memutar baling-baling yang digunakan untuk menangkap energi kinetik dari angin. Selanjutnya energi ini dikonversi menjadi energi untuk memutar rotor. Jumlah balingbaling pada kincir angin umumnya adalah tiga, namun bisa juga lebih. Unit gearbox yang menjadi transmisi untuk turbin angin berfungsi untuk menyalurkan daya dari rotor menuju generator, dengan cara membuat putaran menjadi lebih cepat [13].

Dalam sistem ini, generator menjadi unit terpenting. Fungsinya adalah mengkonversi energi mekanik dari putaran rotor menjadi energi listrik. Untuk meningkatkan kinerja sistem ini, unit pengendali berupa controller dipasang untuk membantu mengendalikan arah poros turbin. Ada pula anemometer yang bertugas untuk mengukur kecepatan angin, serta yaw drive untuk mengatur posisi 
komponen turbin angin, agar mendapatkan posisi paling optimal dengan arah angin, dan juga yaw motor dengan fungsi untuk menggerakan yaw drive [14].

Sistem turbin terbagi menjadi dua jenis, yaitu turbin angin sumbu vertikal dan turbin angin sumbu horizontal. Turbin angin sumbu vertikal mempunyai rotor utama yang disusun secara tegak lurus. Sistem ini memiliki kelebihan yaitu turbin tidak perlu diarahkan ke arah angin supaya efektif [14].

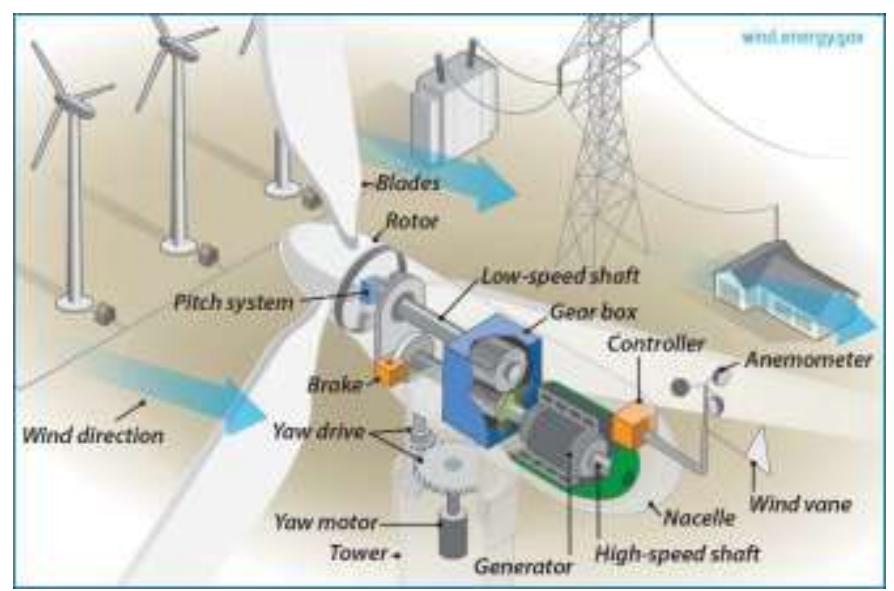

Gambar 3. Skema prinsip kerja energi angin [14]

\subsection{Energi Biomassa}

Nama lain dari energi ini adalah biofuel. Energi ini berasal dari bahan-bahan organik seperti tanaman hasil pertanian, perkebunan, atau limbah industri dan rumah tangga. Contoh paling sederhana dari energi ini adalah kayu. Kayu yang dibakar akan menghasilkan uap serta energi panas. Di samping itu, energi ini juga dapat diperoleh dari hewan dan bakteri. Ada tiga wujud dalam memanfaatkan energi ini, yaitu padat, cair, dan gas. Dua metode umum yang digunakan untuk memproduksi energi ini adalah dengan menumbuhkan organisme penghasil biomass, atau dengan menggunakan bahan sisa olahan makhluk hidup dari hasil industri. Ketika diolah menjadi energi, bahan-bahan ini akan melepaskan gas karbon dioksida $\left(\mathrm{CO}_{2}\right)$ ke atmosfer. Siklus tersebut merupakan bagian dari siklus karbon yang lebih pendek dibanding proses $\mathrm{CO}_{2}$ yang dihasilkan oleh minyak bumi atau gas alam. Umumnya, bahan yang digunakan adalah benda dengan wujud padat yang mudah terbakar, seperti kayu bakar, atau tanaman yang mudah terbakar. Di samping itu, tanaman dapat dibudidayakan secara khusus untuk pembakaran, atau keperluan lain seperti diolah di industri dengan limbah hasil pengolahan yang dapat dibakar sebagai bahan bakar. Di sisi lain, biomassa dalam bentuk briket juga menggunakan biomassa padat dengan bahan baku berupa potongan atau serpihan biomassa padat mentah, atau yang telah melalui proses tertentu seperti pirolisis untuk meningkatkan persentase karbon dan mengurangi kandungan air [15]. Gambar 4 menunjukkan proses detail tentang bagaimana biomassa bisa diubah menjadi energi listrik.

Beberapa langkah pengolahan untuk menghasilkan energi ini antara lain:

1. Pembakaran limbah atau sampah organik kering. Beberapa sumber yang memungkinkan adalah limbah dari hasil pembuangan rumah tangga, industri ataupun pertanian,

2. Hasil fermentasi dari limbah basah, seperti kotoran hewan. Pengolahan limbah tanpa penggunaan oksigen dapat menghasilkan biogas serta kandungan metana mencapai $60 \%$,

3. Fermentasi tebu dan jagung untuk menghasilkan alkohol sekaligus ester yang kemudian dapat diolah kembali menjadi bahan bakar tertentu,

4. Kayu dari pohon-pohon dalam hutan yang diambil sebagai bahan bakar biomassa [15]. 


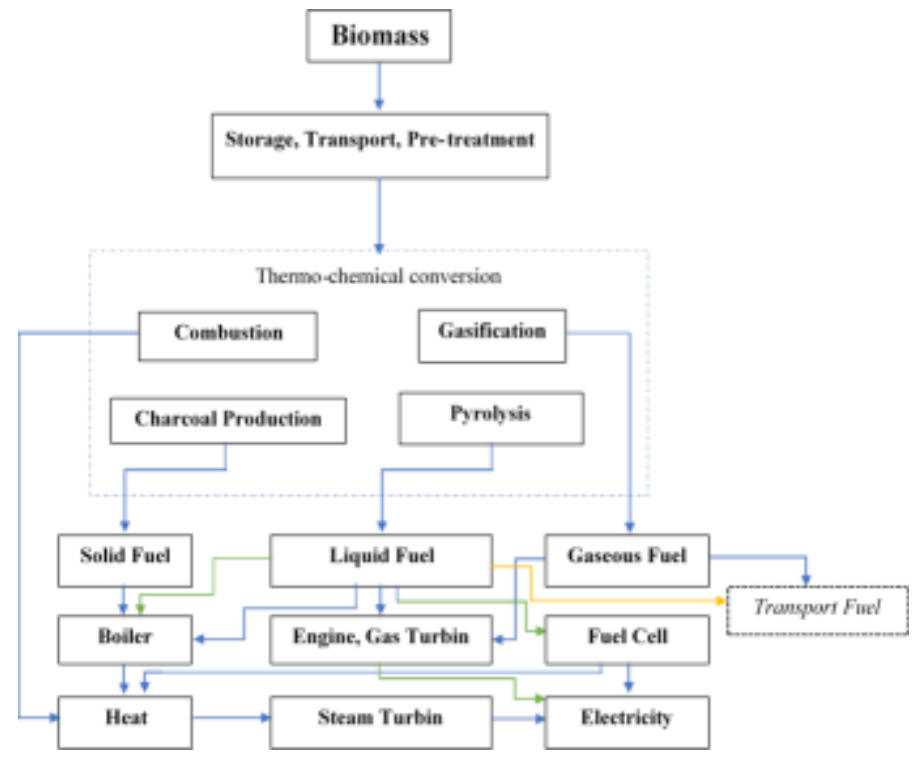

Gambar 4. Bagan prinsip kerja biomassa menjadi bahan bakar dan menjadi energi listrik [16]

\section{METODE PENELITIAN}

Metode penelitian studi ini menggunakan Systematic Literature Review (SLR) [17]. Dalam penelitian ini penulis melakukan pencarian dengan dua kata kunci. Masing-masing kata kunci dan hasil pencariannya ditunjukkan pada Tabel 1.

Tabel 1. Hasil pencarian dari masing-masing kata kunci

\begin{tabular}{|c|c|c|}
\hline No & Kata Kunci & Hasil Pencarian \\
\hline \multirow{3}{*}{1} & Potensi Energi Baru dan Terbarukan & 667.000 (panas bumi) \\
& & 568.000 (angin) \\
& & 190.000 (biomassa) \\
\hline \multirow{2}{*}{2} & Menjadi Energi Listrik & 435.000 (panas bumi) \\
& & 354.000 (angin) \\
& & 94.200 (biomassa) \\
\multirow{2}{*}{3} & Potensi Energi Baru dan Terbarukan; Menjadi Energi & 396.000 (panas bumi) \\
& Listrik; di Indonesia & 338.000 (angin) \\
& Potensi Energi Baru dan Terbarukan DAN Menjadi Energi & 112.000 (biomassa) \\
\hline 4 & Listrik di Indonesia & 40.200 \\
\hline
\end{tabular}

Kata kunci yang pertama adalah "Potensi Energi Baru dan Terbarukan" khususnya Panas Bumi, Angin dan Biomassa. Berdasarkan kata kunci yang pertama, untuk masing - masing EBT, pencarian panas bumi ditemukan 667.000 hasil, untuk energi angin ditemukan 568.000 hasil, dan untuk energi biomassa ditemukan 190.000 hasil. Kata kunci yang kedua adalah "Menjadi Energi Listrik", dengan hasil pencarian untuk panas bumi yaitu 435.000 hasil. Untuk energi angin ditemukan 354.000 hasil, dan untuk energi biomassa ditemukan 94.200 hasil. Untuk menghubungkan kata kunci pertama dan kedua, digunakan kata "di Indonesia". Hal ini untuk memfokuskan data yang akan diambil sebagai referensi penelitian. Hasil pencarian menjadi 396.000 hasil untuk panas bumi, 338.000 hasil untuk angin, dan 112.000 hasil untuk biomassa. Kemudian untuk menggabungkan kedua kata kunci tersebut menggunakan kata "DAN" untuk mendapatkan hasil yang lebih spesifik. Diperoleh hasil 40.200 artikel. Untuk tahun penerbitan jurnal dibatasi dengan minimal tahun 2015, kecuali untuk beberapa pengertian mendasar ada beberapa jurnal tahun 2005 atau di bawah tahun 2015. Dari seluruh artikel yang diperoleh, penulis menyaring hasil artikel dan jurnal yang sesuai untuk mendapakan data yang akurat untuk digunakan dalam penelitian ini. Data yang dikumpulkan bersifat sekunder, yaitu dengan pengumpulan jurnal serta artikel penelitian yang sudah ada, media massa dan laporan dari badan pemerintah khususnya kementrian ESDM. Peneliti 
mengambil data dengan mengkaji ulang informasi dan fakta yang ada, kemudian memparafrase ulang dan memberikan analisis menyeluruh. Data yanng dikumpulkan memuat data terbaru di tahun 2015 keatas kecuali beberapa teori dasar dibawah tahun 2015. Periode pengkajian penelitian jurnal ini secara efektif satu bulan yaitu dari tanggal 24 Juni sampai dengan 24 Juli 2020. Adapun periode penelitian secara terperinci terdapat pada Tabel 2.

Tabel 2. Periode pengkajian penelitian

\begin{tabular}{|c|c|c|c|}
\hline No & Waktu & Bab Pengkajian & Detail Pengkajian \\
\hline 1 & $\begin{array}{l}24 \text { Juni } \\
2020\end{array}$ & $\begin{array}{l}\text { Tujuan dan rumusan } \\
\text { masalah }\end{array}$ & $\begin{array}{c}\text { - Potensi EBT di Indnesia yang sangat memadai } \\
\text { untuk pengembangan menjadi energi listrik } \\
\text { - Beberapa faktor secara garis besar yang menjadi } \\
\text { penghambat progres perkembangan EBT }\end{array}$ \\
\hline 2 & $\begin{array}{l}1 \mathrm{Juli} \\
2020\end{array}$ & Pendahuluan & $\begin{array}{l}\text { Pengambilan data secara umum mengenai EBT } \\
\text { serta pengkajian pandemi covid-19 yang sedang } \\
\text { terjadi dan dampak yang mungkin di timbulkan }\end{array}$ \\
\hline 3 & $\begin{array}{l}5 \text { Juli } \\
2020\end{array}$ & Landasan teori & $\begin{array}{l}\text { Pengambilan data secara teoritis mengenai energi } \\
\text { panas bumi, angin dan biomassa }\end{array}$ \\
\hline 4 & $\begin{array}{l}15 \mathrm{Juli} \\
2020\end{array}$ & Metode penelitian & $\begin{array}{l}\text { Metode yang digunakan yaitu Systematic Literature } \\
\text { Review dan teknik pengambilan data sekunder yang } \\
\text { didapat dari jurnal atau paper dari rentang 2015- } \\
2020 \text { dan sumber dari badan ESDM }\end{array}$ \\
\hline 5 & $\begin{array}{l}19 \text { Juli } \\
2020\end{array}$ & Pembahasan & $\begin{array}{c}\text { Pengkajian ulang data potensi EBT, maupun faktor } \\
\text { penghambat }\end{array}$ \\
\hline 6 & $\begin{array}{l}20 \mathrm{Juli} \\
2020\end{array}$ & Kesimpulan & $\begin{array}{l}\text { Menganalisis hasil pembahasan berdasarkan data } \\
\text { yang ada dan kondisi di masa sekarang yaitu tahun } \\
2020\end{array}$ \\
\hline 7 & $\begin{array}{l}21 \mathrm{Juli} \\
2020\end{array}$ & Abstrak dan referensi & $\begin{array}{c}\text { Membuat ringkasan dari keseluruhan paper dan } \\
\text { tahap penyempuraan }\end{array}$ \\
\hline
\end{tabular}

\section{HASIL PEMBAHASAN DAN ANALISIS}

\subsection{Potensi Energi Panas Bumi, Angin, dan Biomassa Menjadi Energi Listrik}

Sesuai dengan PP No. 79 tahun 2014 tentang kebijakan Energi Nasional, target EBT pada tahun 2025 sekitar 23\% dan 31\% pada tahun 2050 [3]. Berdasarkan data ESDM tahun 2019, potensi EBT mencapai $432 \mathrm{GW}$. Dari potensi tersebut, sekitar $7 \mathrm{GW}$ yang telah dimanfaatkan secara komersial. Hingga tahun 2028 akan ada penambahan sekitar 29 GW oleh PLN berdasarkan Rencana Usaha Penyediaan Tenaga Listrik (RUPTL) 2019-2028. Sementara Rencana Umum Energi Daerah (RUED) yang disusun oleh 34 pemerintah provinsi mengindikasikan total kapasitas terpasang energi terbarukan pada tahun 2025 mencapai $48 \mathrm{GW}$. Tabel 3 menunjukkan potensi total EBT (panas bumi, angin, dan biomassa) menjadi energi listrik di Indonesia, sedangkan Tabel 4 menunjukkan detail di masing-masing wilayah di seluruh Indonesia [18]. 
Tabel 3. Total potensi energi panas bumi, angin, dan biomassa menjadi energi listrik di Indonesia [18]

\begin{tabular}{|c|c|}
\hline Jenis Energi & Potensi \\
\hline Panas Bumi & $17,97 \mathrm{GW}$ \\
\hline Angin & $60,64 \mathrm{GW}$ \\
\hline Biomassa & $31,69 \mathrm{GW}$ \\
\hline
\end{tabular}

Tabel 4. Kapasitas terpasang dan total potensi energi panas bumi, angin dan biomassa menjadi energi listrik di masing-masing wilayah Indonesia [18]

\begin{tabular}{|c|c|c|c|c|c|c|c|c|c|}
\hline \multicolumn{10}{|c|}{ Potensi Energi Terbarukan Indonesia } \\
\hline PROPINSI & Potensi & Terpasang & $\begin{array}{c}\text { Rencana } \\
2019-2028\end{array}$ & Potensi & Terpasang & $\begin{array}{c}\text { Rencana } \\
2019-2028\end{array}$ & Potensi & Terpasang & $\begin{array}{l}\text { Rencana } \\
\text { 2019-2028 }\end{array}$ \\
\hline ACEH & 332 & - & 440 & 894 & - & - & 1174 & - & 170 \\
\hline SUMATERA UTARA & 2316 & 330 & 670 & 356 & - & - & 2912 & - & 159 \\
\hline SUMATERA BARAT & 1035 & - & 650 & 428 & - & - & 958 & 1 & 143 \\
\hline RIAU & 430 & - & - & 22 & - & - & 4195 & 30 & 157 \\
\hline KEP. RIAU & - & - & - & 922 & - & - & 16 & 0.9 & 6 \\
\hline KEP. BANGKA BELITUNG & - & - & - & 1787 & - & 5 & 223 & 16 & 28 \\
\hline JAMBI & 621 & - & 540 & 37 & - & - & 1840 & - & 147 \\
\hline SUMATERA SELATAN & 964 & - & 910 & 301 & - & - & 2133 & 4 & 143 \\
\hline BENGKULU & 780 & & 650 & 1513 & - & - & 645 & 3 & 143 \\
\hline LAMPUNG & 1339 & 220 & 680 & 1137 & - & - & 1492 & 6 & 145 \\
\hline BANTEN & 365 & - & 150 & 1753 & - & - & 465 & - & - \\
\hline DKI JAKARTA & - & - & - & 4 & - & - & 127 & - & - \\
\hline JAWA BARAT & 3765 & 1199 & 795 & 7036 & - & - & 2554 & - & - \\
\hline JAWA TENGAH & 1344 & 60 & 760 & 5213 & - & - & 2233 & - & - \\
\hline D.I.Y. & 10 & - & - & 1079 & - & - & 224 & - & - \\
\hline JAWA TIMUR & 1012 & - & 630 & 7907 & 13 & - & 3421 & - & 50 \\
\hline BALI & 262 & - & 65 & 1019 & 1 & 10 & 192 & - & 0.9 \\
\hline NUSA TENGGARA BARAT & 169 & - & 10 & 2605 & - & - & 394 & - & - \\
\hline NUSA TENGGARA TIMUR & 763 & 10 & 115 & 10188 & - & 29 & 241 & - & 20 \\
\hline KALIMANTAN BARAT & - & - & - & 554 & - & & 1308 & 15 & 69 \\
\hline KALIMANTAN SELATAN & - & - & - & 1006 & - & 70 & 1290 & - & 12 \\
\hline KALIMANTAN TENGAH & - & - & - & 681 & - & - & 1499 & - & - \\
\hline KALIMANTAN TIMUR & - & - & - & 212 & - & - & - & - & 13 \\
\hline KALIMANTAN UTARA & - & - & - & 73 & - & - & - & - & 10 \\
\hline SULAWESI UTARA & 768 & - & 75 & 1214 & - & - & 164 & - & 10 \\
\hline SULAWESI TENGAH & 368 & - & - & 908 & - & - & 327 & - & 10 \\
\hline GORONTALO & 110 & - & - & 137 & - & - & 131 & - & - \\
\hline SULAWESI SELATAN & 163 & - & - & 4193 & 130 & 60 & 959 & - & - \\
\hline SULAWESI TENGGARA & 98 & - & - & 1414 & - & - & 151 & - & 10 \\
\hline SULAWESI BARAT & 162 & - & - & 514 & - & - & 206 & - & - \\
\hline MALUKU & 220 & - & 7 & 3188 & - & - & 33 & - & 46 \\
\hline MALUKU UTARA & 580 & - & 40 & 504 & - & - & 35 & - & 29 \\
\hline PAPUA & - & - & - & 1411 & - & - & 97 & - & 4 \\
\hline PAPUA BARAT & - & - & - & 437 & - & - & 55 & - & - \\
\hline
\end{tabular}

\subsection{Potensi Kapasitas Terpasang Energi Panas Bumi Berdasarkan Level Prediksi 2010-2050}

Potensi panas bumi Indonesia mencakup $40 \%$ potensi panas bumi dunia yaitu sebesar 28,91 GW. Lokasi panas bumi menyebar kurang lebih di 285 lokasi. Tahun 2016 potensi panas bumi yang telah dimanfaatkan baru berada di 9 wilayah kerja dengan 5 lokasi diantaranya di Pulau Jawa. Dalam menjelaskan kapasitas energi yang dibangkitkan, ada beberapa level yang digunakan (Gambar 5). Pada level 1, kapasitas pembangkit panas bumi di tahun 2050 diasumsikan memiliki nilai sebesar 5,78 GW atau setara dengan $20 \%$ dari total potensi yang ada. Selanjutnya pada level 2, peningkatan kapasitas diasumsikan tidak signifikan, namun tetap lebih tinggi dari level pertama denga nilai 8,67 GW pada tahun 2050. Di saat yang bersamaan, kendala dalam pengembangan panas bumi masih ada. Untuk level 3, kapasitas terpasang Pembangkit Listrik Tenaga Panas bumi (PLTP) pada tahun 2050 diasumsikan sebesar 14,46 GW atau 50\% dari total potensi yang ada. Lalu pada level 4, kapasitas terpasang PLTP pada tahun 2050 diasumsikan mencapai 20,24 GW atau $70 \%$ dari total potensi. Pada level ini pembangunan PLTP sudah tidak menemui kendala [19]. 


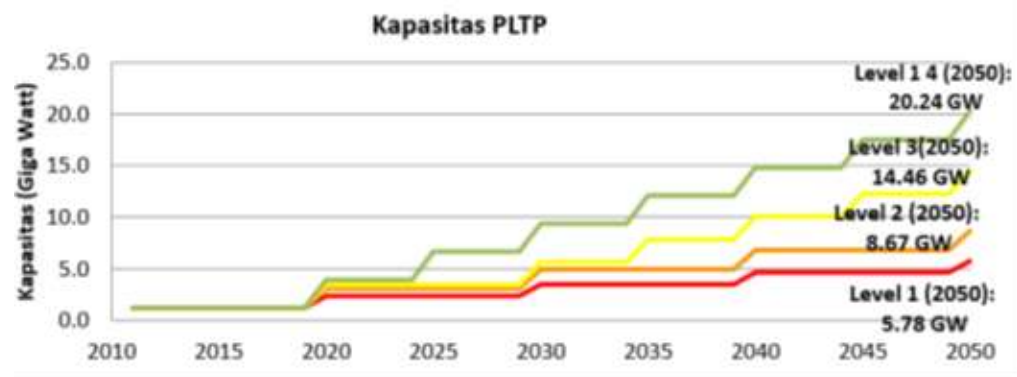

Gambar 5. Grafik kapasitas PLTP level I - IV [19]

\subsection{Potensi Kapasitas Terpasang Energi Angin Berdasarkan Level Prediksi 2010-2050}

Energi angin merupakan salah satu sumber energi terbarukan yang belum secara optimal dimanfaatkan dibanding EBT lainnya. Wilayah yang memiliki kecepatan angin lebih dari $6 \mathrm{~m} / \mathrm{s}$ diantaranya ujung pulau Sumatera, sebagian selatan pulau Jawa, dan bagian utara pulau Sulawesi, diperkirakan potensi energi angin di Indonesia bisa mencapai 61,97 GW. Sedangkan perkembangan dari level 1 ke level 4 sangat signifikan, mencapai lebih dari 6x lipat, seperti ditunjukkan pada Gambar 6 [19].

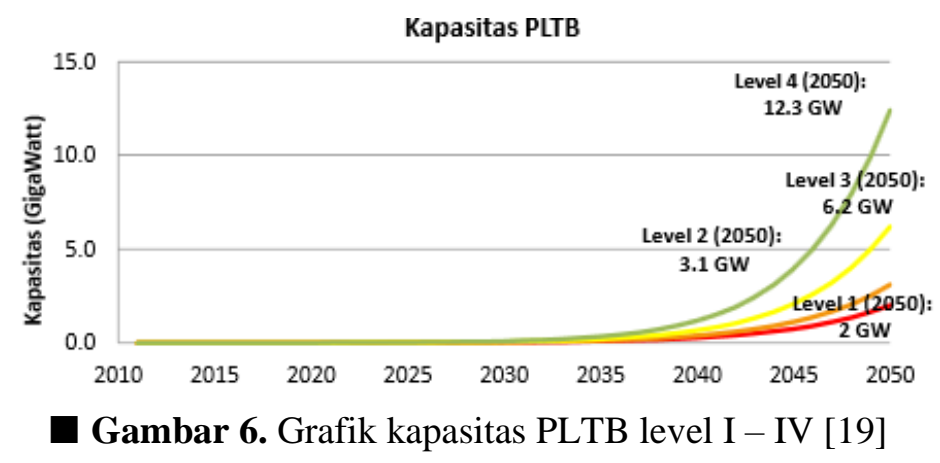

\subsection{Potensi Kapasitas Terpasang Energi Biomassa Berdasarkan Level Prediksi 2010-2050}

Indonesia memiliki kekayaan dan potensi bioenergi yang memadai jika bisa dimanfaatkan dengan baik. Potensi produksi biomassa mencapai 146,7 juta ton per tahun. Dalam perhitungan pada tahun 2050 pembangkit biomassa diperoleh dari biomassa kering dan sektor kehutanan, pertanian dan perkebunan. Potensi kapasitas listrik yang dapat dihasilkan dari sektor tersebut mencapai 24,64 GW. Untuk level 1, kapasitas PLT Biomassa yang terpasang pada tahun 2050 diasumsikan bernilai sebesar 4,92 GW atau setara dengan $20 \%$ dari total potensi yang ada. Lalu pada level 2, kapasitas pembangkit biomassa pada tahun 2050 diasumsikan mencapai $9,86 \mathrm{GW}$ atau bernilai $40 \%$ dari total potensi. Selanjutnya pada level 3 , pembangkit energi dari biomassa pada tahun 2050 diasumsikan mencapai kapasitas dengan nilai sebesar $14,78 \mathrm{GW}$ yang juga setara dengan $60 \%$ dari total potensi. Terakhir, level 4 diperkirakan akan memiliki kapasitas pembangkit biomassa pada tahun 2050 dengan daya sebesar 22,18 GW atau setara dengan $90 \%$ dari total potensi yang ada. Pada level ini, pemanfaatan biomassa untuk pembangkit hampir mencapai titik maksimum [19]. Grafiknya ditunjukkan pada Gambar 7 berikut.

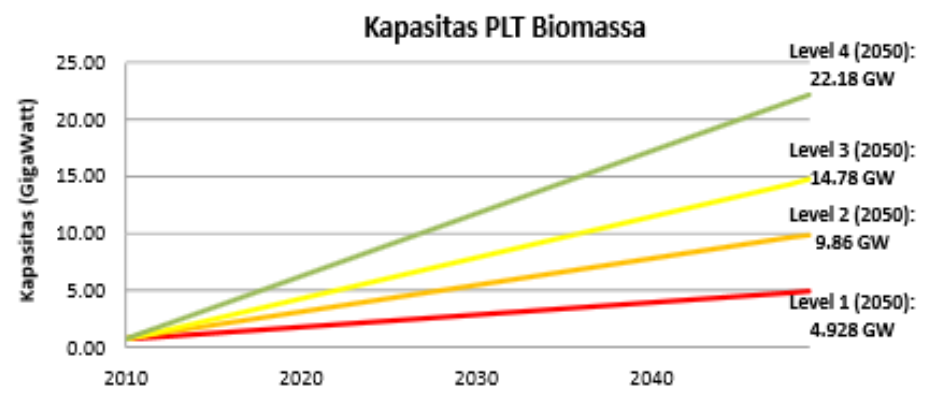

Gambar 7. Grafik kapasitas PLT Biomassa level I - IV [19] 


\subsection{Faktor - Faktor Penghambat Pemanfaatan Energi Panas Bumi, Angin dan Biomassa di Indonesia}

Faktor - faktor yang menghambat lajur investasi, khususnya untuk pembangunan infrastruktur pada bidang energi, adalah keterbatasan pendanaan, koordinasi yang kurang maksimal dalam tahap perencanaan, serta masalah-masalah yang terus berulang saat implementasi.

Keterbatasan pendanaan untuk melakukan investasi dalam pembangunan EBT diantaranya:

1. kesulitan dalam mempertahankan iklim investasi dari tahun ke tahun. Anggaran yang didapatkan untuk pembangunan proyek EBT semakin berkurang. Hal ini dipengaruhi beragamnya kasus birokrasi dan budaya KKN dalam lingkungan pemerintahan sehingga menghambat penyelesaain beberapa proyek di bidang energi, khususnya proyek yang menggunakan dana APBN. Sehingga proses tender memerlukan durasi yang relatif lebih lama, dan berimbas pada lama waktu pengerjaan yang melewati target. Hal ini berakibat dalam hal pelaporan keuangan, pencapaian maupun perencanaan kedepan.

2. Di sisi lain, penyaluran kredit oleh lembaga bilateral serta multilateral juga memiliki dampak dalam faktor ini, karena Perjanjian Penerus Pinjaman atau biasa disebutnya dengan Subsidiary Loan Agreement (SLA) dan perjanjian pencairan dana pemerintah atau disebut DIPA-SLA (Daftar Isian Padu Anggaran untuk Perjanjian Penerusan Pinjaman) memiliki dampak yang sangat besar terhadap pola pikir lembaga - lembaga pelaksana, khususnya dalam menentukan pendanaan bagi berbagai proyek. Hal ini karena Perjanjian SLA dan DIPA-SLA perlu dilakukan dalam prosedur tertentu sebelum perjanjian pinjaman dengan lembaga terkait bisa mendapatkan persetujuan dari kementerian keuangan. Selain itu, proses yang berlangsung lama karena dasar persetujuan atas likuidasi SLA bergantung pada perundingan dalam APBN [20].

Di samping itu, ada koordinasi yang kurang maksimal dalam tahap perencanaan hingga tahap pelaksanaan, khususnya di antara lembaga pemerintahan, seperti kementerian dengan instasi yang menjalankan proyek. Salah satu contohnya adalah mengenai data-data kementerian ESDM dan Dirjen EBTKE yang disediakan harus memiliki tingkat akurasi yang tinggi. Hal ini menyebabkan beberapa rencana yang telah dibuat menjadi sulit untuk dikembangkan, serta memiliki hasil yang tidak maksimal. Ditambah lagi, dukungan pada produksi serta konsumi bahan bakar fosil lebih tinggi daripada sumber energi lainnya. Hal ini dilihat dari pemanfaatannya sebagai sumber energi utama, namun pada saat yang bersamaan, justru mengklaim bahwa banyak pembangkit listrik EBT yang telah dibangun. Artinya, pendanaan dari APBN tidak dimanfaatkan secara optimal [20].

Dari sisi implementasi, yaitu penghentian sementara atas pembebasan lahan serta perizinan dapat menghalangi perkembangan proyek, serta meningkatkan resiko bagi kandidat investor. Banyak ditemukan kasus dari berbagai kelompok masyarakat yang menyatakan kepemilikan atas tanah yang sama. Selain itu, jika PT PLN melewati rute perkebunan, maka akan diminta untuk memberikan kompensasi untuk setiap pepohonan yang berada di wilayah tersebut. Hal ini menyebabkan dana yang dibutuhkan terlalu tinggi untuk pembangunan jalur transmisi. Berbagai target investasi untuk EBT belum terpenuhi karena kapasitas tidak memadai akibat data yang tidak lengkap khususnya beberapa data teknis serta perizinan kontrak tahun jamak yang tidak diterbitkan oleh menteri keuangan, sehingga pelaksanaan proyek menjadi terhambat [20].

Selain hambatan diatas, ada juga hal-hal yang tumpang tindih, yaitu lahan yang berada di kawasan hutan. UU Kehutanan mengkategorikan kegiatan panas bumi sebagai kegiatan pertambangan, sehingga tidak diizinkan masuk ke dalam kawasan konservasi. Kebijakan pemberian subsidi bagi bahan bakar minyak juga menjadi kendala yang menghambat perkembangan EBT di Indonesia [21].

\subsection{Persentase Kapasitas Terpasang Energi Panas Bumi, Angin dan Biomassa Terhadap Potensi dan Rencana Tahun 2019-2028}

Berdasarkan Tabel 2 di atas, EBT tahun 2019 menjadi energi listrik dari tiga sumber energi, yakni panas bumi, angin, dan biomassa, diperoleh data potensi energi panas bumi sebesar 17.976 MW, kapasitas terpasang PLTP sebesar 1.819 MW sedangkan rencana potensi energi panas bumi 2019-2028 sebesar 7.187 MW, jadi persentase energi panas bumi terpasang terhadap potensi energi yang ada sebesar $10,12 \%$, sedangkan persentase energi terpasang terhadap rencana energi panas bumi tahun 2019-2028 sebesar 25,31\%. Potensi energi angin sebesar 60.647 MW, kapasitas terpasang PLTB 144 MW dan rencana potensi energi angin tahun 2019-2028 sebesar 174 MW, jadi persentase energi terpasang terhadap potensi energi sebesar $0,23 \%$ sedangkan kapasitas terpasang terhadap rencana potensi tahun 2019-2028 sebesar 82,76\%. Dan potensi energi biomassa sebesar 31.694 MW, kapasitas terpasang 
sebesar 75,9 MW dan rencana potensi tahun 2019-2028 sebesar 1.524 MW. Jadi persentase energi terpasang terhadap potensi energi sebesar $0,23 \%$ sedangkan kapasitas terpasang terhadap rencana potensi energi tahun 2019-2028 sebesar 4,92\%. Dari data tersebut total energi yang telah terpasang masih belum mencapai target dari rencana potensi energi terpasang tahun 2019-2028.

\subsection{Potensi berdasarkan prediksi tahun 2010-2050}

Berdasarkan hasil data prediksi yang telah di sebutkan di atas, didapatkan bahwa untuk kapasitas PLTP dari level 1 sampai dengan level 4 pada tahun 2010 hingga awal 2020 adalah stabil atau tidak mengalami peningkatan, untuk level 1 sampai dengan level 3 mengalami peningkatan setelah awal tahun 2020, kemudian stabil sampai di tahun 2030 awal, sedangkan untuk level 4 dari tahun 2020 sampai dengan tahun 2050 mengalami peningkatan setiap 5 tahunnya sehingga mencapai 20,24 GW di tahun 2050. Dan untuk level 3 mengalami peningkatan dari tahun 2030 ke tahun 2050 setiap 5 tahun sekali hingga mencapai 14,46 GW. Untuk level 1 sampai level 2 dari tahun 2030 hingga tahun 2050 peningkatan stabil setiap 10 tahunnya pada level 2 di angka 8,67 GW dan level 1 di angka 5,78 GW.

Sedangkan untuk kapasitas PLTB di prediksi sampai dengan tahun 2050 yaitu saat ditahun 2010 - 2035 stabil dan mulai mengalami peningkatan di tahun 2035 - 2050 masing-masing di angka 12,3 GW untuk level 4, disambung dengan 6,2 GW di level 3, lalu 3,1 GW di level 2, dan 2 GW di level 1.

Dan untuk kapasitas PLT Bio di prediksi sampai dengan tahun 2050 mengalami peningkatan yang stabil dari tahun 2010 - 2050 masing-masing di angka 22,18 GW untuk level 4, dan ada 14,78 untuk level 3, diikuti dengan 9,86 GW untuk level 2, dan terakhir 4,928 GW untuk level 1.

\subsection{Faktor penghambat EBT tidak mencapai target yang direncanakan}

Target pemanfaatan EBT sebagai energi listrik pada tahun 2025 sebesar 23\% terhadap bauran energi. Tiga diantaranya adalah panas bumi, angin, dan biomassa. Dari ketiga energi tersebut kapasitas terpasang di Indonesia yang mensuplai paling besar terhadap potensi yang ada yaitu panas bumi dengan angka sebesar 10,12\%, sedangkan kapasitas terpasang untuk energi angin dan biomassa masing-masing sebesar $0,23 \%$ dari potensi yang ada. Dari hasil persentase tiga energi tersebut terdapat faktor yang menjadi penyebab sulitnya EBT berkembang di Indonesia, diantaranya adalah pendanaan yang terbatas, perencanaan yang tidak terkoordinasi dengan baik, serta beragam kasus birokrasi dan budaya KKN dalam lingkungan pemerintahan. Disamping itu pemerintah yang memberikan subsidi bahan bakar minyak bagi masyarakat juga menjadikan berkurangnya minat masyarakat turut serta mengembangkan EBT di Indonesia yang bisa dikatakan cukup besar potensinya. Di samping itu, aksesibilitas pengembangan infrastruktur masih belum mendukung dengan pengembangan EBT, pemenuhan target investasinya tidak dapat tercapai. Di tambah lagi dengan kesulitan untuk mendapatkan izin eksplorasi wilayah hutan Indonesia yang mana lokasi geothermal justru banyak terletak di wilayah hutan.

\section{KESIMPULAN}

Berdasarkan hasil persentase kapasitas terpasang terhadap rencana energi tahun 2019-2028 dari energi panas bumi, angin, dan biomassa, energi angin atau PLTB memiliki persentase terbesar yaitu 82,76\%. Disusul oleh panas bumi dengan nilai sebesar $25,31 \%$ dan biomassa dengan nilai sebesar 4,92\%. Maka di tahun 2020 ini, EBT belum bisa mencapai target yang sudah ditetapkan oleh pemerintah. Banyak faktor yang menghambat pencapaian tersebut, seperti faktor pendanaan, perencanaan yang tidak terkoordinasi, dan juga implementasi yang sulit. Ditambah lagi dengan pandemi COVID-19 yang masih terjadi, sehingga implementasi semakin melambat. Hal ini membuat anggaran dana dialihkan untuk fokus ke penanganan pandemi tersebut. Secara tidak langsung anggaran untuk proyek energi menjadi semakin terhambat perkembangannya. Kebijakan energi yang masih digunakan saat ini belum secara efisien memberikan dampak pada perkembangan energi terbarukan di Indonesia. Perlu penelitian dan pembahasan lebih lanjut dan menyeluruh untuk mengurangi faktor penghambat agar setiap tahun tetap mengalami peningkatan penggunaan EBT. Dari sisi masyarakat sendiri, perlu diberikan edukasi maupun penyuluhan untuk ikut serta melakukan pengembangan EBT terutama di berbagai wilayah di Indonesia dengan potensi yang sangat besar. 


\section{DAFTAR PUSTAKA}

[1] Permenkes Nomor 9 Tahun 2020, "Pedoman PSBB dalam rangka Percepatan Penanganan COVID 19", 2020. Internet: https://peraturan.bpk.go.id/Home/Details/135220/permenkes-no-9-tahun2020 [1 Juli 2020].

[2] Internet: https://jabarprov.go.id/Inilah Alasan Naiknya Tagihan Listrik Selama PSBB, [10 Juli 2020].

[3] PP Nomor 79 Tahun 2014 Tentang Kebijakan Energi Nasional. Internet: https://www.bphn.go.id/data/documents/14pp079.pdf. [1 Juli 2020]

[4] R. Wahyuningsih, "Potensi Wilayah Kerja Pertambangan Panas Bumi di Indonesia", Kolokium Hasil Lapangan- DIM, 2005.

[5] UU nomor 27/2003, Tentang Panas Bumi dan UU nomor 20/2002, Tentang Ketenagalistrikan. Internet: https://jdih.esdm.go.id/storage/document/uu-20-2002.pdf. [1 Juli 2020]

[6] A. Prasetyo, D. Notosudjono, H. Soebagja, "Studi Potensi Penerapan dan Pengembangan Pembangkit Listrik Tenaga Angin di Indonesia”, Program Studi Teknik Elektro Fakultas Teknik Universitas Pakuan, Bogor, Jawa Barat.

[7] J.W. Simatupang dan K. Sulistiohadi, "Portable Wind Turbine for Energy Recharging Device Applications," Journal of Electrical and Electronics Engineering (JEEE) President University, vol. 1, no. 1, pp. 19-24, 2016.

[8] A.A.G.M. Pemayun, "Pembangkit Tenaga Biomassa", Jurusan Teknik Elektro dan Komputer, Universitas Udayana, 2017.

[9] A.I. Pratiwi, M. Asri, "Analisis Pembangkit Listrik Tenaga Biomassa Berbasis Tongkol Jagung”, Fakultas Teknik Universitas Ichsan Gorontalo, Dielektrika, [P-ISSN 20886-9487] [E-ISSN 2579650x], vol. 5, no.2, pp. 108-115, Agustus 2018.

[10] M. Suprayogi, etc.,"Energi Baru, Terbarukan dan Konservasi Energi”, Jurnal Energi Media Komunikasi Kementerian Energi dan Sumber Daya Mineral, Edisi 022016.

[11] Suharyati, et al., "Outlook Energi Indonesia 2019”, ISSN 25273000.

[12] Kompasiana, "Energi Panas Bumi Sebagai Energi Terbarukan", Internet: https://www.kompasiana.com/tiur/56801b4d3f23bdb90c082179/rekomendasi-energi-panasbumi-sebagai-energi-terbarukan, 28 Desember 2015. [1 Juli 2020].

[13] "Skema Prinsip Kerja Energi Panas Bumi", Internet: https://www.cnzahid.com/2016/12/sistemkerja-pembangkit-listrik-tenaga, Desember 2016. [10 Juli 2020].

[14] T.A. Adlie, et al., "Perancangan Turbin Sumbu Horizontal 3 Sudut Dengan Daya Output 1 KW", Universitas Samudra Meurandeh-Langsa 24416, Aceh, ISSN 2356-5438.

[15] "Biomassa - Pengertian, Prinsip, Manfaat \& Contoh Energi", Internet: https://rimbakita.com/biomassa, [12 Juli 2020].

[16] Arhamsah, "Pemanfaatan Biomassa Kayu Sebagai Sumber Energi Terbarukan", Jurnal Riset Industri Hasil Hutan, vol.2, no.1, pp. 42-48, Juni 2020.

[17] J.W. Simatupang, M. Galina, C.W.D. Lumoindong, "A Survey on The Implementation of FTTX Service and Technologies in Indonesia: Best Practices and Lessons Learned from Other Asian Countries," TRKU Journal (ISSN: 04532198), vol. 62, no. 03, April 2020.

[18] A.P. Tampubolon, et al., "Laporan Status Energi Bersih Indonesia/Potensi, Kapasitas Terpasang dan Rencana Pembangunan Pembangkit Listrik Energi Terbarukan 2019, Institute for Essential Service Reform (IESR), Maret 2019.

[19] R.E. Caraka, P.C. Ekacitta, "Simulasi Kalkulator Energi Baru Terbarukan (EBT) Guna Memenuhi Ketahanan Energi di Indonesia", Statistika, vol. 16, no. 2, pp. 77-88, November 2016.

[20] M. Lauranti, E.A. Djamhari, "Transisi Energi yang Setara di Indonesia: Tantangan dan Peluang," Friedrich Ebert Stiftung, Desember 2017.

[21] S. Riyandi, 21 Mei 2012. Internet: https://www.merdeka.com/uang/hambatan pengembangan energi terbarukan. [12 Juli 2020]. 